\title{
INSTRUMENTOS DE POLÍTICAS PÚBLICAS. FACTORES CLAVES DE LAS CAPACIDADES ESTATALES
}

\author{
Fernando J. Isuani (•) \\ Universidad Nacional de General Sarmiento
}

\section{RESUMEN}

En los últimos años se ha dado una revalorización del rol del Estado, la que convive con la conciencia de sus fuertes dificultades para resolver problemas que afectan a la sociedad. Para adoptar y cristalizar estrategias de reforma tendientes a mejorar las capacidades estatales y poder ser optimista respecto de sus resultados, entendemos necesario previamente generar conocimiento sobre los factores que las condicionan. Este trabajo asume que los instrumentos de política pública constituyen un factor clave en las capacidades del Estado. A partir de los resultados de un estudio de caso realizado en 2010 sobre la política del agua en la provincia de Buenos Aires (Argentina), se deja en evidencia del modo en el que los instrumentos de política pública condicionan las capacidades estatales. A partir de ello, se propone una serie de orientaciones destinadas a nutrir futuras estrategias de reforma estatal.

\section{PALABRAS CLAVE:}

capacidades estatales, instrumentos de políticas, reforma del Estado.

\footnotetext{
(•)E-mail: fisuani@ungs.edu.ar
}

\section{ABSTRACT}

In the last years, there has been an appreciation of the role of the state which coexists with strong awareness of their difficulties and constraints to solve different social problems. To adopt and crystallize reform strategies aimed at improving state capacities, and be optimistic about their results, it is necessary to generate knowledge about the factors that condition them. This paper points out that public policy instruments are a key factor of state capacities. Thus, from a case study in 2010 on water policy in the province of Buenos Aires (Argentina), the work shows how public policy instruments determine the strengthening of state capabilities and presents a series of guidelines at nurturing future state reform strategies.

\section{KEY WORDS:}

States capacity, policy instruments, State reform. 